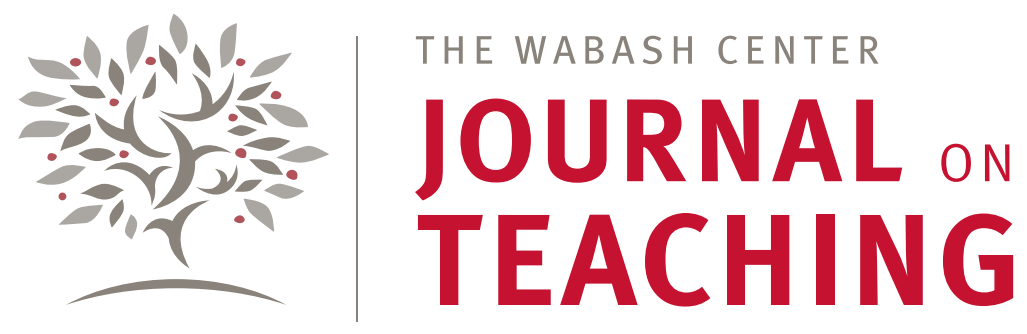

CONVERSATION

\title{
Conversation on the Scholarship of Teaching
}

\author{
Thomas Pearson \\ Wabash Center
}

Kwok Pui Lan

Candler School of Theology

\author{
Eugene V. Gallagher \\ Connecticut College, emeritus
}

\begin{abstract}
This Conversation was recorded during the final weekend meeting of the participants in the Wabash Center's Colloquy on Writing the Scholarship of Teaching (2017-2018). Over the previous year, each of the Colloquy participants had been developing their own essay on a topic in the scholarship of teaching religion and theology. The conversation begins with reflections on the scholarly peer review process, but quickly expands to debates about the contours of the scholarship on teaching and the value of this literature-both as an author and a reader-to cultivating a successful teaching practice.
\end{abstract}

\section{KEYWORDS}

writing about teaching, peer review, mentorship, genre, scholarship, SoTL, audience, transferability, gatekeeping, iteration

Thomas Let's start by discussing the prompts The Wabash Center Journal on Teaching provides for peer reviewers. Pearson $^{1} \quad$ You've been developing essays for the journal, which has involved writing and receiving peer review, based on these prompts. How relevant did those prompts seem to you as an author, and as a reviewer? What was your experience of being held accountable, so to speak, to these particular prompts? Did they prompt relevant feedback for what you were trying to achieve as an author and for what you were trying to communicate to the author you were reviewing? How would you compare them to the Teaching and Learning Inquiry's review prompts we've looked at (2020)? ${ }^{2}$

Hussein As an author I really liked the prompts. They help by indicating clear directions on what I should be Rashid thinking about as I write. When I sent my draft off to my external reviewer, I was asking myself, have I hit all of these points? It helped me anticipate and fill possible gaps.

\footnotetext{
1 Conversation participants, in order of appearance: Thomas Pearson (Wabash Center for Teaching and Learning in Theology and Religion), Hussein Rashid (Barnard University), Eugene V. Gallagher (Connecticut College, emeritus), Mindy McGarrah Sharp (Columbia Theological Seminary), Lea F. Schweitz (Lutheran School of Theology at Chicago), Jenna Gray-Hildenbrand (Middle Tennessee State University), Zandra L. Jordan (Stanford University), Benjamin E. Zeller (Lake Forest College), David B. Howell (Ferrum University), Almeda M. Wright (Yale Divinity School), Martin Nguyen (Fairfield University), Kwok Pui Lan (Candler School of Theology), Heather White (University of Puget Sound), G. Brooke Lester (Garrett-Evangelical Theological Seminary), Beverley Foulks McGuire (University of North Carolina, Wilmington).

2 The link to the "TLI Review Form" is at the end of the second paragraph (https://journalhosting.ucalgary.ca/index.php/TLI/about\#PR).
} 
On the reviewing side, it was very helpful to be instructed that I should be writing to the author, not the editors. It made me realize that I had responsibility to another human being. This is a problem with a lot of the peer reviews. It's easy to feel responsible instead to the computer screen, which is inherently alienating, and I think sometimes causes me to be a bit more caustic then I intend to be because I'm only talking to the screen, not another human being. My academic training is to be critical and address my critique to the editor. I never realized how far that had taken over my process for writing peer reviews until I got this form asking me to write for the author.

Eugene V. There are a couple of different roots for this. First, the Wabash Center ethos of hospitality is focused on Gallagher supporting faculty to have the conversations they need to have, rather than dictating the content of what they should talk about. Secondly, we've learned that it is not helpful for a reviewer to strike out at an acute angle, saying "Here's what your article should have been about"-criticizing the author for not writing the article that the reviewer would have liked to have written on the topic. It's much better to try to stand alongside the author and try to help them write the best version of the essay that they want to write.

Thomas There's a little a bit of tension there. As an editor, I spend a lot of time talking authors through what the Pearson scholarship of teaching is. I'm often responding to an article which is not framed or focused appropriately for our journal. But I'm very careful to compliment them on what they have written. It becomes a question of whether it's appropriate to the scope and mission of the journal. I can tell them, "This is very interesting; it's written really well. If you want to publish it in our journal, here's what we need you to do."

That's the tack I try to take because we often get submissions from very accomplished authors but they don't understand the genre we're publishing in the journal. Writing about teaching is not something that's learned in graduate school. So potential authors often don't know that they don't know how to write about teaching. Editing this journal is a real teaching process, involving a lot of long emails. I'm not actually trying to help them write the best article they want to write. I'm trying to help them write the best article that I see potentially for the journal-without saying that what they've written is bad. I often see more possibilities in the article than the authors seem to. Sometimes I just want to write it for them.

Mindy The sense of mentorship you are talking about is important. What you're doing is mentoring authors to McGarrah say what they can uniquely contribute to the field in a way that makes the best contribution to the scope Sharp and mission of the journal. I'm wondering what it would look like to have a specific prompt that was a mentorship charge to peer reviewers.

In my peer review, I thought of mentorship as sort of a preamble to the comments I made to the author, and my peer reviewer made the same kind of preamble in her comments to me. It's like an invitation to the author to go back to the article and bring it to the next level. It's more than an affirmation. "This is what you're doing well and here's where I look forward to seeing you write more." Peer review can become something that encourages the author to get back to work on the piece. Sometimes reviews can feel so demoralizing that I just want to throw the manuscript out and start again or do something else.

Lea F. I appreciate the way the prompts hold the genre loosely. I noticed that in the other rubric we studied, Schweitz the sections emerged so clearly named from the frameworks presented (Teaching and Learning Inquiry 2020). The way that the fit in the genre is cast, it felt much more restricted in the other examples. In the prompts for The Wabash Center Journal on Teaching, the fit for the genre is still really open to hold what the author wants to contribute-whether it's the disciplinary field or religious studies or seminary teaching. I appreciate that the mentoring in the genre is held loosely, so that the shape of the genre can adjust as people's best contributions find their way into it. The prompts hold space for them.

Jenna I was struck by the use of the word "sympathetic" in the opening lines of the instructions: give "a Gray sympathetic analysis ..." and "offer suggestions that will help an author write the best possible version of Hildenbrand the article the author intends to write." I think that's what opens this up to mentorship. 
Zandra

Jordan

Benjamin E. Zeller

Thomas

Pearson

Hussein

Rashid

David B. Howell

Almeda M. Wright

Eugene V. Gallagher
Shifting the topic somewhat, I'll say that I like the four categories (focus and argument, analytical leverage, organization and development, scholarship of teaching), each elaborated with a series of questions. But I often struggled with overlap, especially between the first one and the third one.

As I read the article to write my review, I would jump around from category to category as a comment would occur to me. I didn't write the review in the order dictated by the prompts. As I read, I would start putting a comment under one category, and then decide that it belongs under another one instead. Then I would write, "see also under number three." This isn't necessarily a problem, but I think there is some bleeding into other categories.

I think that number two and four overlap ("Analytic Leverage” and "Scholarship of Teaching”). I've done three or four peer reviews for the journal now. The first time, I remember I typed all the answers for number four into number two. And then when I got to number four I said, "Oh, wait, this material in number two belongs down here instead." But I'm used to it now. This last time I think I just put all the comments into number two and then I cut and pasted down to number four after the fact. I find it impossible to talk about analytic leverage for an article about teaching unless l'm talking about its use of the scholarship of teaching.

We see a lot of interesting submissions that draw on theorists in their academic-content field, so to speak. They'll have a theory of ethics, or communication, for example, that they use to gain analytic leverage on what they're experiencing in their classrooms.

As I've been writing my essay, my writing group has been helping me fill in some of the SoTL material, but what I'm really using for analytical leverage is my discipline. How do questions about religious literacy and Orientalism affect the way in which I construct the content of a course? I'm putting in the SoTL material after the fact. It wasn't part of the original scope.

The paper I reviewed wasn't SoTL-rich, but it felt like there was enough analytic leverage to analyze what was happening in the classroom. Somebody with more background in SoTL could certainly put in that material, but it felt like a very complete paper without explicit references to SoTL material. It was still very much focused on the classroom and teaching and learning.

It just strikes me that one advantage of having an article that is more SoTL rich is that SoTL is able to make public our thinking about what's going on in our classrooms. If you include references to SoTL literature then you're connecting to what's already out there in the public. For example, you're writing your paper about teaching your "Intro to Islam" course. I may never teach that intro course. But I do teach other intro courses, and if you're connecting your analysis with some of the SoTL material it might make it easier for me to transfer the principles about what you're discovering in your Islam course to my biblical studies course. So the SoTL material may help readers who aren't as directly involved in your specific project or the content of your course to apply it analogously to their own teaching context.

The way that I read the fourth prompt is somewhat different from how I read number two. It's not necessarily how much SoTL material an author references, but do they show how their argument is connected to another conversation in the scholarship. Have they shown me the debate around teaching Islam, for example. Or, my article is about gender and diversity in the classroom, and my intervention is a different side of that debate. As I was reading Mindy's paper, I was asking whether there is a conversation that she's connecting to. And not just quoting it, but expanding that conversation.

Often my job as an editor is to point authors to the conversation they should be joining. We sometimes get first-time submissions from authors who have been widely recognized as good teachers. They think it's enough for their article to report on their practice. And I can see that they're effective teachers, and what 
they're describing is innovative and maybe even original. But is that enough? Can a reader transfer that description to make sense of their own teaching context? Is it just description, or is the analysis sufficient if there is no recognition of the principles that are at stake, principles that apply more abstractly to different teaching contexts?

Martin I've been thinking about Hussein's example of the "Intro to Islam" course, and what role SoTL plays in an Nguyen article like that. And David's point that referencing SoTL literature might make the article accessible to teachers in other fields. But on the other hand, for readers who are in Islamic Studies, it's not necessarily the SoTL literature that draws them in. It's the analytic leverage from their disciplinary field that they're already familiar with-that's what's going to make the article appealing or not.

Almeda M. This raises the question for me about who the journal audience really is. "Teachers of theology and Wright religion” is such a broad banner, including so many disparate disciplines. I don't know if I feel comfortable writing for such a broad field. It's like l'm writing to the lowest common denominator. So what would be appropriate analytic leverage? I could write it one way, or I could write it another for a different audience. How broad is my audience? I need to pick my audience. What is the audience that fits with where my heart is for this article?

Kwok Pui Since I am the relatively new Associate Editor, I often find it is my role to question how we define the Lan parameters of what counts as the scholarship of teaching. Gene and Tom have been doing this for longer than I have, and I am the first racial minority to serve as an associate editor of this journal. This makes me keenly aware of whether the journal is serving racial minorities. The demographics of theological education are changing rapidly. Currently 38 percent of students in ATS accredited schools are racial and ethnic minorities. That is quite high. So the question needs to be asked how we equip teachers of all different backgrounds to teach a diverse body of students. And so from my vantage point, the scholarship of teaching is not just pedagogy in the classroom. Whether I can be an effective teacher is not just how I handle classroom dynamics. That is only a small part of it. How should we understand the broader parameters of scholarship about teaching?

That is why I keep returning to Patricia and Gene's article on "Sketching the Contours of the Scholarship of Teaching" (Killen and Gallagher 2013). It names different genres in the scholarship, and presses us to name what we are looking for and where it fits.

We received a Forum of short articles describing a quilting exercise the authors had participated in as part of a Wabash Center Early Career Workshop (Parks et al. 2019). In the original version of this submission, some of the authors connected the exercise to their racial and ethnic identities, but did not talk about teaching at all. Gene, Tom, and I had a very interesting conversation about how this collection of essays could fit into the journal or not. Is it enough to reflect on your identity? Your vocation? Or do you need to show how it connects to your teaching practice?

Hussein The Wabash journal always struck me as too narrow and not relevant to what I'm doing. Too Christian Rashid focused; too narrowly focused on classroom mechanics. But it was Martin's involvement with the Wabash Center blog (2020), raising questions about minority status, Islamic Studies, and what voices are present, that led me to look again. So there may be value in being explicit about people's situation informed by race, gender, class, sexuality, and other identifiers.

Eugene V. For me, the bottom line is transferability. Can the insights of an article be generalized so as to be transferable Gallagher to other teaching contexts and other course content areas? It can't just be about you, the author. You have to have a sense that there are other people involved in the conversation you want to join. Now, I don't ever say that an essay on theological education needs to reach people teaching "Intro to World Religions"; we have a sense of a pretty broad spectrum. But the idea of making your thinking public through publication suggests that you have some kind of audience in mind. It needs to be more than just you. 
Thomas

Pearson

Heather White

Thomas

Pearson

Almeda M. Wright

Kwok Pui Lan
From theological education to religious studies is a pretty broad spectrum. I'm not always sure they represent two sides of the same spectrum or maybe two different spectrums altogether. I'm working with a group of authors who are writing about using modern language "communicative pedagogy" techniques when teaching biblical Hebrew. They're very articulate about their teaching practices and the learning challenges students face-but how many of our readers have this problem in their classrooms? How is this transferable beyond teaching biblical languages? Is there something here for other readers to learn?

And then too, I hear what Pui Lan is saying, that a focus on the mechanics of classroom teaching can exclude the identity and vocation issues that are rightfully central for many faculty. Excluding these questions sort of brackets, or makes normative, a particular historically white identity of the teacher and the student.

Thinking about the question of audience and transferability, those things can often be presented as quite neutral, but really it's an issue of gatekeeping. I was struck by a prompt in one of the peer review forms we looked at for comparison. It asked about the "appropriateness of insight" in the article. And when you start asking about what is "appropriate," the gatekeeping function becomes really evident.

So it's important that the reviewer's responses are not yes or no answers (as they are in some of these forms), but that the reviewer takes the opportunity to expand and develop what makes this essay appropriate or not. "Appropriate for whom?" And it could be the case that the audience being imagined for The Wabash Center Journal on Teaching is narrower than it could or should be. We need to push at this gatekeeping function. There are critical questions around audience and what is "appropriate" that need to be continually highlighted.

That's very helpful. I'm struck by how much gatekeeping is inherent to the definition of any journal, of any field. Graduate programs are all about gatekeeping. Which school of thought are you in? Where do you publish? And the scholarship of teaching is different because we don't learn this in our graduate programs, we're inventing it on the job, so to speak. And there's a range of venues for writing about teachingeverything from the ATS's Theological Education, to the AAR's Spotlight on Teaching (and Spotlight on Theological Education) and the AAR-Oxford Teaching Religious Studies Series, and the much broader field of scholarship on teaching emerging from the Carnegie CASTL model (2020), and how that practice has been picked up by different disciplines in the academy. ${ }^{3}$ We're all doing this somewhat differently; we're all inventing or defining a field by our publication and review process.

At the Wabash Center we tend to construe our work as simply supporting faculty conversations about teaching, not determining what those conversations need to be. But with the journal we're playing a real gatekeeper role, defining what counts as scholarship on teaching for our journal-what that conversation is about. Of course, we do this unconsciously and implicitly in our other programing as well.

The question arises, then, whether the peer reviewers are trained to reflect on the parameters of what counts as scholarship on teaching for the journal. There is more than one way to write an article on teaching. Not every article needs to be of the "show and tell" variety, analyzing classroom practices. Is this reflected adequately in the prompts for review? These prompts function as a rubric for assessing the article. Where, then, really, is the gatekeeping getting done?

I'm also thinking about it from a marketing point of view. In another life I might have sold used cars. You have to think about whether the journal is something that your colleagues are going to want to read. Some of our colleagues will be looking for something to help them in their teaching techniques. Others will not see the value of that. They need to be persuaded. We need to think about what is relevant to our colleagues today. Our faculties are under so much stress. Higher education is not a very healthy environment right now. From a marketing standpoint, some of the articles we publish need to address

\footnotetext{
3 ATS's Theological Education (https://www.ats.edu/theological-education-archives); AAR-Oxford Teaching Religious Studies Series (https://www.aarweb.org/ node/237); AAR Spotlight on Teaching (http://rsn.aarweb.org/spotlight-on/teaching); Spotlight on Theological Education (http://rsn.aarweb.org/spotlight-on/ theo-ed); and the Carnegie CASTL model (http://archive.carnegiefoundation.org/scholarship-teaching-learning.html).
} 
these wider issues. Because otherwise many of our colleagues may not see the relevance of reading an article on how to teach a specific topic. It's not something they think they really need to learn. We need to get them in the door; we need to make the journal more visible. We need to be addressing the bigger issues that are shaping the teaching environment, so that people might be interested. Otherwise we're just preaching to the choir. We have to be constantly asking ourselves, what are the big questions, the big issues, shaping the field in theological education and undergraduate contexts? That way we can generate interest.

Mindy I had a colleague who responded to a previous call for papers on teaching in precarious institutions. It was McGarrah quite a conundrum, because as an untenured faculty member this colleague was quite vulnerable in the Sharp institution's precarity. And it wouldn't be possible to provide anonymity. Sometimes the most important issues are the most difficult to write about, because we're vulnerable to them. This is true for contingent faculty as well.

Hussein Additionally, writing about teaching doesn't usually count toward promotion and tenure. There's no one Rashid for whom this counts as part of their scholarly work in their discipline. So trying to get authors to write for the journal must be difficult, especially for contingent faculty.

Benjamin I would push back on that some. I know that as chair of my department at a liberal arts college, when I'm E. Zeller looking through CVs to hire full- or part-time colleagues, the one that says "Wabash" is the first one I'm going to call.

David B. I guess context matters, in all sorts of ways. At Ferrum College, where I've become dean, we have a new Howell faculty orientation program and regular activities to help faculty develop as teachers: monthly lunches, book groups. Teaching is very important in our tenure decisions. You have to have the ability to think about and talk about your teaching. The Wabash journal, and the scholarship of teaching, can give new faculty that language. And that's necessary for success at Ferrum.

G. Brooke At my institution, a tenured faculty member with Wabash experience just asked me to write some text for Lester the faculty handbook to set a faculty policy for how publishing in the scholarship of teaching should count toward contract renewal, tenure, and promotion. And it passed through the faculty unanimously. But I don't know that this would happen everywhere. It takes leadership from senior faculty members to change a culture, to change these requirements.

Hussein I think those are great stories. But you have to realize that you're sitting in a position where you can make Rashid those decisions. We have to realize that we're living in a world in which something like 80 percent of the professoriate is now contingent faculty.

Jenna I think it's important to go back to what Pui Lan was saying, that we need to be addressing bigger issues Hildenbrand than just classroom practices. Hussein is writing an article on how ideas of religious literacy and Orientalism create challenges for how he teaches his Introduction to Islam course. We have said that SoTL literature can be a bridge to make this analysis transferable to other teaching contexts. Unfortunately, there isn't much SoTL literature on these kinds of big issues. Or, another example would be my article with Rebekka King on aligning our courses, discipline, institution, and profession. I'm hearing Pui Lan say that these bigger issues aren’t being addressed by SoTL literature.

Beverley There is literature on these topics, though. Look at the research being produced in schools of education. McGuire If you're in conversation with the folks who are running your center for teaching excellence, or with your school of education, then you're putting yourself in conversation not only with the research but also with what's happening on your campus.

Jenna Yes, that's right. That's what we are trying to do in our article-align with all these different stake holders. Hildenbrand There are multiple bridges for transferability. 
Beverley McGuire

Hussein Rashid

Eugene V. Gallagher

Beverley McGuire

Mindy Sharp

Thomas Pearson

Eugene V. Gallagher
Right, but you need to adopt the language of educators. Terms like alignment and assessment are the language of educators and administrators. And if we don't reference it as such, if our articles are written as though we invented these concepts ourselves, then we're not seen as entering and furthering this already robust conversation, and writing in The Wabash Center Journal on Teaching will not be seen as legitimate scholarly activity. You need to be putting yourself into the conversation. This is what the center for teaching excellence is trying to do on my campus - to have a larger conversation on our campus, so that the SoTL work we do will count toward tenure and promotion. But to count in this way, we need to be referencing SoTL research.

Listening to these comments and thinking about the individual essays in my writing cohort, we were all in some way dealing with the issue of religious literacy. Now, a prominent book in my field, which has changed a lot of the conversation in our discipline, is Richard King's book Orientalism and Religion (1999). He doesn't name it as such, but about a third of his book is critiquing the notion of religious illiteracy. There's a lot of SoTL literature about meeting students where they are, to work with the knowledge they bring with them into your course, to start with that as a basis for understanding your field. But this is a problem when a lot of their knowledge is racist, Islamophobic, and orientalist. It's a real problem. So here our disciplinary research really needs to critique, or contribute to this SoTL literature on pre-knowledge.

I like the King example. I think what you're talking about here is taking our disciplinary scholarship and "SoTL-izing it." If you take this disciplinary knowledge seriously, it has real implications for teaching. My task can be to tease out the implications, to point out how this should be affecting curriculum design, course design, and teaching in the classroom.

It's helpful to realize that there are proximate SoTL conversation partners from within our own discipline. You don't have to read a whole wall of books about teaching before you can say anything about your classroom. There are teaching implications in these scholarly works. That's where l'm often disappointed in the Oxford series on teaching. Many of the essays review all this important scholarly stuff that you should teach, but they don't get around to addressing the question of what implication this new scholarly literature has for how we teach.

I like that idea: to take an important book in your field and SoTL-ize it. How does it change how you teach?

Exactly. That would be fun. Not just how it changes things for students, but also how it changes things for where I am, and where I fail myself and my students and my guild, from my old training and habits that make it hard to innovate. That's what I wrestle with in my article. I want teachers to be reflecting on their own malformation - to do this work well, so that we can do this work of the scholarship of teaching and learning well together.

We're going to turn now to discuss how participating in the scholarship of teaching and learning has, or could, change the way you actually teach. We're going to hear first from Gene and Pui Lan and then open it up to everyone to discuss.

My engagement, historically, goes back to when my former institution decided to have a teaching and learning center, and I was the only one nominated to be the director. I felt that position imposed on me the responsibility for serving as a broker between the faculty and the vast scholarship on teaching. So that's when I started reading this literature. I think my experience working in and on SoTL has expanded my consciousness of possibilities and expanded my attention to why I'm doing what I'm doing. I have found both of those possible. 
I still have teaching moments where I'll be doing something that's not working particularly well, and l'll be fanning through my mental Rolodex, "Oh, I remember a book that said something relevant about this." It might have been a couple years ago, but l'm able to draw on it sometimes in a just-in-time (or often just a little too late) fashion. But I still find the slog through vast amounts of this SoTL stuff sometimes frustrating. It's not always, for me, news I can use. But I've gotten better with my decisions over the years about what I should read, which helps a lot.

Kwok Pui Like Gene, my encounter with the scholarship of teaching really began with Wabash. It was almost twenty Lan years ago when I participated in a Wabash workshop for mid-career faculty. We were given a list of articles about teaching and could get copies of any of the articles on the list. That was when I first read the essay "The Seasons of an Academic Life" (Knefelkamp 1990). I was also exposed to a lot of articles on teaching from the perspective of racial and ethnic minorities.

Since then I have had the opportunity to serve on the leadership team of several workshops, and meet people who are very serious about teaching. I have learned so much from these conversations and have been able to put into practice some of the things I have learned.

For example, in one of the workshops I learned about something called "enduring understanding." Students are exposed to many new ideas and understandings in my course-ideas about the Bible, mystical accounts of creation, and contemporary religious issues. A workshop participant taught me to ask this question at the end of the course, "what are three enduring understandings that you want to remember and carry forth." This has proved to be very helpful for my students. In another example, a Wabash workshop participant taught me to introduce formal debates in the classroom, which require students to assume different positions and explore different arguments that they otherwise would not consider. I've also learned how to pay attention to learning outcomes. I am not a big fan of the assessment exercises we have to do at our schools. But I have learned that I have to be aware of what the mechanism is to measure the learning outcomes. Relying on student evaluations is not enough. As editors we are always pressing authors to explain how they know if a particular teaching strategy they have described actually works or not. So now l'm always asking myself that question as well. How do I know if it works?

Hussein When I was a graduate student, my graduate advisor was adamant that we use the Bok Teaching and Rashid Learning Center on campus. It's a great center. They used the phrase, "the craft of teaching." They knew the theory behind what they were saying, but they never really engaged us with that theory. They always focused on the practical aspects for improving classroom experience and course design. It was not until I came to Wabash that I realized that there is a whole scholarship behind what they were teaching me. It's been fascinating for me to discover how much of my understanding about teaching has been informed by that scholarship without knowing it existed. Now l'm going back and reverse engineering in a sense, which is giving me a new level of intentionality to why l'm doing what I'm doing in the classroom and what I'm hoping to achieve. I feel like l'm completing the circle.

David B. The scholarship gives me a language or a lens to understand what l'm experiencing in the classroom. Until Howell you have a name for something, often times you don't really see it. So I think the scholarship of teaching has allowed me to become more aware of classroom and learning dynamics, and to pick up on what students are experiencing.

Zandra My discipline, the field of rhetoric and composition, lends itself to paying more attention to the student Jordan experience. When teaching writing, we teach it as an iterative process, using multiple drafts and revisions to scaffold toward larger assignments. So, there are often multiple opportunities to see how students are learning and to think about what that may mean for your teaching practice. All of this is built in to composition as a discipline.

At the same time, as we all know, being an expert in your subject matter is not the same as being able 
to teach it well. So I think whatever one's subject matter is, it's helpful to be able to take a step back and consider, what am I actually doing and how am I helping students come to a deeper knowledge and understanding of this material in such a way that they can employ it. The scholarship of teaching helps us do that. It's important to have institutional support for investing the time needed to engage these questions. That's one of the reasons why Wabash is such a gift, even for someone whose field really lends itself to that kind of questioning and investigation. We all just get busy, and it's easy to get into the routine of work and family and whatever else is going on and not make time to take a step back and consider how students are learning and how one's assignments are connected to the goals that we say matter for the course. That can very quickly get lost in the busyness of the routine of being in academia.

Thomas Pearson

Lea F.

Schweitz

Thomas

Pearson

Eugene V. Gallagher
What I really like about the Randy Bass essay, "What's the Problem?" (1999), is that it helps to articulate the sense of teaching as an academic pursuit, that there academic questions you can ask of teaching.

When you said, Zandra, that "writing is an iterative process," I was thinking that teaching too is an iterative process. You're going to be teaching the course again next year. I think the base-level of teaching as an academic activity is just to stop and reflect on your own teaching. The more you can turn that into an academic problem to be analyzed and addressed, I think, the more fulfilling teaching can be. We are trained as academics.

So we are always trying to articulate what the value is of the scholarship of teaching that I read-how does it actually impact my teaching? But I think the greater impact is the scholarship of teaching that I write. To have identified an intellectual "problem" in your students' learning, designed a response to that problem, and then analyzed the whole process through writing-that can be transformational.

I've been frustrated because my schedule over the past five years has not allowed me to teach a single course for a second time, and most of my teaching has been team teaching. My article has helped me think about modules within courses, and these modules are iterative, even if the course as a whole is not. Thinking of this lack of iteration as "a problem" has allowed me to think about how to modulize my teaching, and thereby rethink my teaching again as an iterative process.

One of the challenges I face in my job is how to make the scholarship of teaching available and accessible and valuable to faculty who are too busy to read it. It's just so overwhelming to see bookshelves of this stuff lining the walls. Perhaps a professor needs to think more about how to grade assignments. I can point them to twenty-five books they can read on that. It's just not very helpful. I need to give them a one page handout or a single helpful article or website with links.

So I'm curious, Gene-you started our conversation describing yourself as a "broker" of teaching resources for your faculty, and for yourself, really-how do you decide what to read and when? Do you pick it up when you're not thinking of anything specific, like summer reading, and then you continue to think about it over the years and come to apply it? Or are you more likely to have a specific problem in mind, the way Randy Bass describes, and you set about to research it and go find an answer?

Probably both. I think one important thing that Pui Lan pointed out earlier was that when you get involved with a community of people who have some shared conversational topics, that gives you an agenda for reading. When I came back to Wabash a second time and a third time and kept hearing about, let's say, Stephen Brookfield or Donald Finkel, I decided that I should probably order those books and make sure they're on my desk (Brookfield 1987, 1990, 2009; Brookfield and Preskill 1999; Hess and Brookfield 2008; Finkel 2000; Finkel and Arney 1995). To be a responsible conversation partner, there are certain things I think you need to read.

The other thing l'd say is that I tend to benefit from bite-size nuggets. That's why I still like the Teaching Tactics we publish in the journal. Even when they're not something l'm likely to try in my own classroom, they're worth reading just for that sense of contrast. And then there are publications like The Teaching Professor (now a blog), which is comprised of short and easily digestible summaries of longer essays or a body of literature. 
So, I think there are different registers of involvement, from just a baseline familiarity to keep going, and then every once in a while sitting down for a couple weeks and working with some specific literature, say on classroom discussion. And then if I'm trying to write something, then l've got to really dig in and find out what other people have been saying.

There are different modes of engagement, different reasons for engagement.

Martin Writing this essay, and being in conversation with others in this colloquy has greatly deepened my Nguyen appreciation of the scholarship of teaching. Now I am much more likely to dip into it with questions from my teaching. When I think of where my colleagues in the field are going with their questions about teaching, however, it tends to be blogs (which Wabash provides) or a teaching workshop at a conference (which Wabash also organizes). But honestly most of them are going to Facebook. I think we all know of Facebook groups where people come to ask questions and share resources and strategies. Of course, I find this very useful, but it also seems very similar to what we criticize our students for doing, which is going to Google for their research.

Hussein Yes, and I'm thinking of a Facebook group for Islamic studies professors in which some of the suggestions Rashid and exercises are flat-out atrocious, because nobody's thinking about what it means for our discipline. "If my students like it," seems to be the standard. What are we actually teaching them? We can't really talk about that in a Facebook group because it is not the space in which to have that conversation.

Martin Maybe we can think of the Facebook group as a gateway to the blog, which in turn is a gateway to the Nguyen conference workshop, which is a gateway to the Wabash Center itself or The Wabash Center Journal on Teaching.

Beverley I'm intrigued by that: "Do students like it." I can see an analog in the student evaluations of our teaching. McGuire The forms are trying to measure student engagement, but the focus should be on student learning. We know that our tenure and promotion is based on things like "Did students like it." But to be a professor with integrity we should be concerned about what students are actually learning, and helping to facilitate that learning.

Almeda M. Just a caveat: I really want us to be careful to make sure that "liking it" and "learning it" are not mutually Wright exclusive categories. Likewise, I am clear that students can be engaged in a rigorous debate, and hate it. So engagement is also not a standard of whether or not they “liked it." There's room for a lot of nuance in these categories.

I was also thinking, in response to Hussein, that maybe the criteria that students "like it" is too low a bar, but at least the Facebook group has some sort of criteria. At least they're looking for answers. Because a lot of people are just teaching the way they were taught and not even trying to look for different activities or different assignments that might enhance students' learning (or engagement, for that matter).

I want to second the notion of teaching as an iterative process and Facebook and blogs as gateways to further reflection on teaching.

David B. $\quad$ To follow up on Gene's mention of The Teaching Professor, there are other publications such as Faculty Howell $\quad$ Focus, which provides a daily short nugget about teaching, based on or excerpted from the literature. These can pique my interest in something that I then investigate further, or is at least on my radar screen.

These sorts of publications are not going to be tied to our specific discipline or field of teaching. But l've been teaching in a one-person department for a number of years and have found that getting involved in teaching and learning conversations is a way to talk to colleagues in other departments. They have introduced me to all sorts of perspectives and writing that I would probably never have come into with. 
I like coming to Wabash and having the disciplinary discussions but I have found these cross-disciplinary conversations and the more general-focused SoTL literature valuable precisely because it gets me out of my discipline.

Kwok Pui When I need to learn something, I often watch those "do-it-yourself" videos on YouTube. There are videos Lan on fixing the plumbing, cooking a dish, and everything else. Students, too, rely on Facebook and YouTube for what they need to learn. Everyone is learning this way today. So how can we tell teachers that they need to read a long article on teaching? No one has time. We need to make it easier, digestible. That's why we have some shorter essays in the journal, and Conversations with teachers, which can be easily consumed. We should be making short videos, just two or three minutes long. We have to realize that today people are learning in lots of different ways, not just reading long scholarly articles.

Thomas I hear what you're saying. And I think that's the key to making teaching resources available. But I want to Pearson maintain a space at the end of the spectrum for sustained scholarly reflection on our teaching practice, because it's through focused effort that we improve. There's the old adage that the one who does the work does the learning. So that's an important reason to continue writing the scholarship of teaching, and maybe a reason to continue reading it. Maybe. But probably not the best way to market it.

G. Brooke Lester

One of the ways that the scholarship of teaching and learning has affected my teaching is that it helps me to relax more. In the movie Philadelphia (2014), there's a line that Tom Hanks uses as a mantra when things are in crisis: "Every problem has a solution. Every problem has a solution." In the model I was given in graduate school, there wasn't even talk of design. The course syllabus and the way things were done, that was just how things were. You didn't talk about whether you could do it this way or that way instead.

It all seemed like a well-oiled machine that existed before us and would exist after we were gone. For me, that was associated with a kind of distance and studied formality between the instructors and the students. There was nothing to be questioned-which meant that when I started teaching and things would go wrong, it seemed like there was nothing to be done about it, because this was just how the machine worked. It was before me, and it would be after me.

But through the scholarship of teaching and learning and other avenues I became aware that you can tinker with a course, and you can tinker for intentional reasons. You can try something else and have a plan. So now when I'm teaching and something's not working, I can just admit that it's not working and I can try something else. The first time you have a flat tire, it's a nightmare. But by your fourth flat tire, it's easy to recognize and it's not an emergency; “Oh, yes, it's a flat tire. I'm just fixing a tire."

With that idea, I find that over time I've been much more able to relax with my students and not try to be like the great inscrutable Oz behind a curtain about the elements of the course. I'm comfortable to let the machinery show a little bit, and my activity to show, because they're adults. I've been really grateful for how I'm able to have more informal, more relaxed, more honest professional relationships with my students, with all the gears and duct tape of the machinery showing - to let them see me changing the tire sometimes in mid-course.

I don't know if anybody else has had experiences with this. I see a correlation between these two things: that the course is a machine that's always in need of repair and always needing parts swapped out; and a growing ability to be vulnerable to my students and not have to keep up a façade all the time.

David B. Brooke, I think what happens is that we accept teaching as a public act. On the one hand teaching is Howell the most public thing that we engage in. We interact with dozens or hundreds of students through a semester. But on the other hand, it's all kept very private from colleagues, from peers. The scholarship of teaching makes public what's going on in the classroom. So you're participating in that, and you see the vulnerabilities and the failures as well as the successes; it frees you up in saying, "Okay, l'm not the 
only one who fell flat on my face, and I can learn." Or, "it was a really good positive experience." Usually, it wasn't because I was good but because the students took over. So it's sort of making public what's going on in classrooms, and I think it frees us up.

Zandra It's important to remember what Mindy reminded us of earlier, that some people are positioned in a Jordan more vulnerable place, which makes writing about teaching a different experience. I think it's important that we question who can do this work and what kinds of risks they may be taking when they do it.

Almeda M. There's so much layered in that, and I think also layered in what David was sharing about making certain Wright things public. There is so much vulnerability.

I feel there's an assumption, because I'm a religious educator, that I should know lots about teaching. And I'm invited often to share at faculty meetings different strategies for how to be more inclusive, for example, or different strategies for how to teach $X, Y$, and $Z$ in ways that are attentive to, say, different learning outcomes. And this is a blessing and a curse. This year in particular, I was up for review, and I felt myself thinking "No, this is not a time for people to come and observe any of my classes." I felt strange that this was my gut reaction, because in other years (when I felt my position was more secure and I was less vulnerable) I felt like "of course. This is what I do. Come. Let's have fun."

So the dynamics around this are very interesting, and I'm not certain how we break or resist those dynamics in order to create cultures and systems that value this type of communal reflection on practices that many of us share-even if we're doing it in the little fiefdoms in our classrooms.

What I have gained in particular from my time at Wabash, but also from reading more of the related literature on teaching, is that SoTL pushes me to think about my teaching and the scholarship of teaching more. Usually we go to SoTL when we encounter a problem. But there's sometimes when people presume that you are good at something, and the literature makes you pull back and say, "Well what was it actually in that thing (assignment, activity, and so forth) that worked? Can we repeat this?” Maybe it was a great semester, but I don't actually know if we can do it again next time. Maybe it was just a fluke. So that has been helpful for me, in the end, to reflect again and wonder what really did we do and how did that work? And this critical reflection helps us to be more intentional for future teaching.

Thomas So that brings you back to what Brooke was saying earlier about the importance of intentional design, Pearson and continuously tinkering with that and fixing flat tires to see if it works better now. I see that as crucial to success in teaching. But then, at the same time, there is the performance of the design, the execution. It seems to me that the design is more the site of the scholarship of teaching. That's where you can SoTL-ize things. That's where you can analyze and reflect, and that's where the public review of teaching takes place. But the performance can be so spontaneous, intuitive, personal, so personality driven. It's a persona. As Almeda was just saying, you don't really know why that went so well or what it was. You just find yourself inhabiting a space with your students and all this amazing stuff is happening.

There's certainly a relationship between the two, but it seems like the intentional design aspect is a lot more susceptible to our academic analysis. I think of what Pui Lan said earlier about the boundaries of what counts for the scholarship of teaching, and where reflection on identity and vocation fit. I wonder if a lot more of that comes out under the performance part of teaching, the persona. And as Zandra was reminding us, how that kind of performance is available, accessible, to some people and not to others and there's a lot of vulnerability and power and bias about that.

Kwok Pui There is also the assumption that teaching only takes place in the classroom, which I constantly resist. Lan Teaching has so many dimensions. You are in the classroom with students, and then you go to chapel to worship, sharing a very different kind of experience with them. I think this experience is equally and sometimes even more important. Think of the professors that had the most impact on you. Someone could be a lousy teacher, but they have offered you a way into a new field that is so important to you. 
I think there is a cultural difference here. I contributed a chapter on East Asian perspectives to a book on mentoring. In the Confucian way, teaching is modeling, teaching is about life. Teaching is not just about knowledge. It's more about wisdom. And how do you teach that? That is a very tall order. That is why I think that sometimes Asian or Asian-American colleagues coming from that culture have such a high expectation for teachers. I really liked what Brooke said about relaxing. You meet other people who are also struggling. You don't need to be perfect the first time. And then, too, there is a body of literature that shows that if you are a racial minority or a woman you tend to get worse student evaluations (Barsow 1995; Reid 2010).

G. Brooke Lester

Mindy Sharp

Almeda M. And you also don't necessarily get that from your centers for teaching and learning. doctoral programs.

Mindy Right.

Sharp

Almeda M. Sometimes there is such a focus on design that we don't know how to describe or write about execution or Wright performance. You need a good design, but the best-laid plans can go really wrong. And then how do you regroup? There is more literature about how to regroup when you have not designed well and things go wrong. But with such varied contexts and such varied personalities, we need to learn how to make tweaks and changes through out, so that we hold our best designs tentatively, and hold our designs in ways that

we recognize that they need to be implemented with grace and finesse. It's an art, and not a science.

Mindy $\quad$ Yes. And remember that we learn too. I'm not just there to teach. I'm also there to learn.

At the lowest point, I had asked every student to come see me individually, and they did by the end of the semester. One said, "I'm just not willing to learn anything from you." And I said, "You can hold that opinion, but I don't feel that way about you. You're still a student in this class, and I think we can still learn together." But it took curiosity and wonder and patience and prayer and everything else to be able say this is a space of learning and try to make it so-even when things are going so badly. You don't necessarily learn that in 


\section{BIBLIOGRAPHY}

AAR Teaching Religious Studies Series. New York, NY: Oxford University Press. https://www.aarweb.org/node/237.

Barsow, S. A. 1995. "Student Evaluations of College Professors When Gender Matters." Journal of Educational Psychology 87: 656-65. https://doi.org/10.1037/0022-0663.87.4.656.

Bass, Randy. 1999. “The Scholarship of Teaching: What's the Problem?” Inventio 1, no. 1.

Boyer, Ernest L. 1990. Scholarship Reconsidered: Priorities of the Professoriate. Princeton, NJ: Carnegie Foundation for the Advancement of Teaching.

Brookfield, Stephen D. 1987. Developing Critical Thinkers: Challenging Adults to Explore Alternative Ways of Thinking and Acting. San Francisco, CA: Jossey-Bass.

Brookfield, Stephen D. 1990. The Skillful Teacher: On Technique, Trust, and Responsiveness in the Classroom. San Francisco, CA: Jossey-Bass.

Brookfield, Stephen D. 2009. Becoming a Critically Reflective Teacher. San Francisco, CA: Jossey-Bass.

Brookfield, Stephen D., and Stephen Preskill. 1999. Discussion as a Way of Teaching. San Francisco, CA: Jossey-Bass.

Carnegie Foundation. 2020. Carnegie Academy for the Scholarship of Teaching and Learning (CASTL) Higher Education. Stanford, CA: Carnegie Foundation. http://archive.carnegiefoundation.org/scholarship-teaching-learning.html.

Chick, Nancy L. 2018. SoTL in Action: Illuminating Critical Moments of Practice. Sterling, VA: Stylus.

Demme, Jonathan. 2014. Philadelphia. Culver City, CA: Columbia Tristar. DVD.

Faculty Focus. Madison, WI: Magna Publications. https://www.facultyfocus.com/.

Finkel, Donald L. 2000. Teaching with Your Mouth Shut. Portsmouth, NH: Boynton/Cook.

Finkel, Donald L., and William Ray Arney. 1995. Educating for Freedom: The Paradox of Pedagogy. New Brunswick, NJ: Rutgers University Press.

Foster, Charles R. 2002. "The Scholarship of Teaching in Theology and Religion: A Wabash Center Advisory Committee Conversation." Teaching Theology and Religion 5 (4): 192-200. https://doi.org/10.1111/1467-9647.00138.

Gallagher, Eugene V. 2009. “The AAR Teaching Series.” Teaching Theology and Religion 12 (1): 24-36. https://doi.org/10.1111/j.1467-9647.2008.00478.x.

Gravett E.O. 2016. "The Scholarship of Teaching and Learning in Religious Studies." Journal of the American Academy of Religion 84 (3): 589-616. https://doi.org/10.1093/jaarel/lfwoo6.

Hess, Mary E., and Stephen D. Brookfield. 2008. Teaching Reflectively in Theological Contexts: Promises and Contradictions. Malabar, FL: Krieger.

Hutchings, Pat, Mary Taylor Huber, and Anthony Ciccone. 2011. The Scholarship of Teaching and Learning Reconsidered: Institutional Integration and Impact. San Francisco, CA : Jossey-Bass.

Killen, Patricia O. 2007. “Midrange Reflection: The Underlying Practice of Wabash Center Workshops, Colloquies, and Consultations." Teaching Theology and Religion 10 (3): 143-149. https://doi.org/10.1111/j.1467-9647.2007.00342.x. 
Killen, Patricia O., and Gallagher E.V. 2013. "Sketching the Contours of the Scholarship of Teaching and Learning in Theology and Religion.” Teaching Theology and Religion 16 (2): 107-124. https://doi.org/10.1111/teth.12020.

King, Richard. 1999. Orientalism and Religion: Postcolonial Theory, India, and "The Mystic East." New York, NY: Routledge.

Knefelkamp, L. Lee. 1990. "Seasons of Academic Life: Honoring Our Collective Autobiography." Liberal Education 76 (3): 4-11.

Kwok, Pui Lan. 2018. “Mentoring from East Asian Perspective.” In Mentoring: Biblical, Theological, and Practical Perspectives, edited by Dean K. Thompson and D. Cameron Murchison, 164-78. Grand Rapids, MI: Eerdmans.

McKinney, Kathleen. 2007. Enhancing Learning through the Scholarship of Teaching and Learning: The Challenges and Joys of Juggling. Bolton, MA: Anker.

McKinney, Kathleen. 2013. “SoTL Bibliography-Selected Sources on the Field of SoTL.” Normal, IL: Illinois State University. https://sotl.illinoisstate.edu/downloads/sotlbiblio2013.pdf.

Reid, Landon D. 2010. "The Role of Perceived Race and Gender in the Evaluation of College Teaching on RateMyProfessors.com.” Journal of Diversity in Higher Education 3 (3): 137-52. https://doi.org/10.1037/a0019865.

Spotlight on Teaching. Atlanta, GA: American Academy of Religion. http://rsn.aarweb.org/spotlight-on/teaching.

Spotlight on Theological Education. Atlanta, GA: American Academy of Religion. http://rsn.aarweb.org/spotlight-on/ theo-ed.

Teaching and Learning Inquiry. 2020. "Peer Review at Teaching and Learning Inquiry." Teaching and Learning Inquiry: The ISSOTL Journal. https://journalhosting.ucalgary.ca/index.php/TLI/about\#PR.

The Teaching Professor. Madison, WI: Magna Publications. ISSN 0892-2209, elSSN 2578-9899. https://www.teachingprofessor.com/.

Theological Education. Pittsburgh, PA: Association of Theological Schools. ISSN 0040-5620. https://www.ats.edu/ theological-education-archives.

Wabash Center. 2020. Reflective Teaching (blog). https://www.wabashcenter.wabash.edu/resources/blog/.

The Wabash Center Journal on Teaching. Crawfordsville, IN: Wabash Center for Teaching and Learning in Theology and Religion. https://www.wabashcenter.wabash.edu/journal/.

Weimer, Maryellen. 2015. Enhancing Scholarly Work on Teaching and Learning: Professional Literature that Makes a Difference. Hoboken, NJ: John Wiley \& Sons. 
